\title{
EFFECTS OF SUBSTITUTION OF CORN FOR COMMERCIAL RATION ON PERFORMANCE AND PLASMA CHOLESTEROL IN KUB CHICKENS
}

\author{
Edi Erwan ${ }^{\star 凶}$ \\ Department of Animal Science, Faculty of Agriculture and Animal Science, State Islamic University of Sultan Syarif Kasim Riau, 28293, Indonesia \\ Email: erwan_edi@yahoo.com; 00:-0000-0002-5306-1582 \\ supporting Information
}

\begin{abstract}
The aim of the present study was to evaluate growth performance and plasma total cholesterol (TCHO) concentration of KUB chickens fed by substitution of commercial feed with corn in 1 of day-old chick of KUB were raised for 10 weeks in two dietary groups including only commercial feed (group A) and a commercial feed substituted by $30 \%$ corn (group B). Data were analysed by T-test. The results showed that there was no significant effect of the treatments on feed intake, body weight (BWG) and feed conversion ratio (FCR) in KUB chickens. Similarly, plasma TCHO concentration did not show any difference between two experimental rations. However, total income of commercial feed substituted with $30 \%$ corn was higher than commercial feed. It was concluded that corn could be used at $30 \%$ to substituted commercial feed without significantly affecting the KUB chicken performance and TCHO. Present research considered usefulness of corn as a potential alternative of commercial feeds in KUB chickens in Indonesia.
\end{abstract}

Keywords: KUB chickens, Feed Intake, Body Weight Gain, Feed Conversion Ratio, Commercial Feed, Corn

\section{INTRODUCTION}

The use of native chicken in tropical countries varies among countries and from community to community within a region (Padhi, 2016; Yakubu et al., 2020). Recently, the poultry production in Indonesia has been given significant economic prospect especially towards provision of chicken carcasses in an effort to fulfill community demand of nutrition (Puspani et al., 2011; Harianto et al., 2019). Population of native chicken in Riau Province from year to year continues to increase along with consumer tastes towards native chicken. This fact is reflected in population growth and demand for native chickens, which has increased from year to year (Bakrie et al., 2003). According to the Central Statistics Agency the number of native chickens in 2014, 2015 and 2016 were 3,327,820, 3,746784 and 3,896,655, respectively (Central Bureau of Statistics, 2017). Indigenous chickens contributed in meat production about 292,710 tons in period 2011-2015. Recently, indigenous chicken production includes almost $16.7 \%$ of total of market share of commercial meat-type poultry in Indonesia (Tangendjaja, 1999). Considering this potential, solutions should be sought to increase population and productivity. To fulfil the demands of indigenous chicken meat in Indonesia, it has been followed by the finding of native KUB chicken as moderately improved native chicken breed. KUB chicken is a superior native chicken produced by the Indonesian Agency for Agricultural Research and Development, Indonesia (Hidayah, 2019). The KUB breed has some advantages such as high hatchability, low feed conversion ratio and high rates of egg production (160-180 eggs/year) (Sartika, 2016) as well as considering aa a meat type breed (Hidayah et al., 2019), in compared to their previous generations as well as local chickens.

One of the keys to success in maintaining KUB chicken is to meet their nutritional needs through the provision of rations that are in accordance with the standards of livestock needs. In general, farmers buy commercial rations that are marketed to have nutritional standards. The feed is the largest cost component, which is about $70 \%$ of the total production cost in poultry (Teguia and Beynen, 2005). Therefore, indirectly the ration is a determinant of the level of profits of farmers. The price of commercial rations sold in markets and poultry shops is considered very expensive by farmers. Therefore it is very important to look for ration giving strategies to reduce feed costs. One alternative that can be taken to reduce the cost of feed is to reduce the portion of the commercial ration provided by one of the raw materials that contain high calories to the performance of the chicken.

One of the main feed ingredients in poultry in preparing rations as an energy source is corn. This feed ingredient has several advantages including easy digesting, palatable and does not contain anti-nutritive substances. In addition, corn also contains xanthophyll substances which can increase the yolk on the yolk, feet and chicken carcass skin. Aside from being a feed source for carbohydrates, the ingredients of this ration are also a source of protein, namely: albumin, globulin, prolamin, glutelin, and nonprotein nitrogen. According to Scott (1982) yellow corn compound 3,370 kcal / kg of 
metabolic energy (EM), $8.6 \%$ crude protein, $3.9 \%$ fat, $2 \%$ crude fiber $0.02 \%$ calcium and $0.1 \%$ phosphorus. In addition, Suarni and Widowati (2007) stated that corn has other advantages including containing $12.19 \%$ dietary fiber which functions to reduce total cholesterol (TCHO), LDL levels and blood glucose. Another advantage of corn is that it contains vitamin A or carotenoid and vitamin E which functions as natural antioxidants that can increase the body's immunity and can inhibit degenerative cells. The content of several essential minerals, such as $\mathrm{K}, \mathrm{Na}, \mathrm{P}, \mathrm{Ca}$ and $\mathrm{Fe}$ are also found in corn.

Several previous studies have shown that replacing some commercial rations with corn does not reduce chicken performance. For instance, Puspani et al. (2011) revealed that substitution commercial feed up to $20 \%$ with corn did not alter feed consumption and FCR in broiler chicken. Winarti and Wiranti (2013) fed diet substitution of broiler commercial feed with corn up to $40 \%$ did not adverse growth and FCR in native chickens. Furthermore, Munira et al. (2016) in their research results reported that there were no significant difference on feed intake, body weight gain (BWG), carcass weight and carcass percentage of super native chickens when fed fermented $10 \%$ rice bran in ration compared to control. These findings indicate that one alternative that can be done in an effort to reduce the cost of raising chickens both broilers and native chickens is to replace some commercial rations with energy source feed ingredients.

To our knowledge, there have been no reports regarding the effect of substitution of commercial feed with corn on performance and plasma TCHO in KUB chicken. Therefore, the purpose of this study was to determine the effect of substitution of commercial feed with corn on performance and plasma TCHO in KUB chickens. In addition, evaluation of corn energy source for economical broiler production also was evaluated.

\section{MATERIALS AND METHODS}

This research was carried out at the Poultry Division Field Laboratory, Faculty of Agriculture and Animal Science, State Islamic University of Sultan Syarif Kasim Riau, Indonesia in 2018.

\section{Ethical approval}

Chickens were handled and managed accordance with the recommendations in the Guide for the Care and Use of Animal, at the Faculty of Agriculture and Animal Science, State Islamic University of Sultan Syarif Kasim Riau, Pekanbaru, Indonesia.

\section{Animals and ration}

This study used 50 DOC KUB chickens purchased from local breeding farms and placed in 2 enclosures (25 per plot). All birds were distributed with uniform body weight and water was provided ad-libitum. One day before the experiment. Placement of chickens into the cage was done randomly. Chicken was put into the cage done two weeks after the cage was cleaned and washed. Likewise, the treatment was given randomly. The size of the enclosure for each unit is $75 \mathrm{~cm} x$ $60 \mathrm{~cm}$ width and $60 \mathrm{~cm}$ height. Each cage was equipped with a ration container and drinking water container. This study consisted of 2 treatments, each consisting of $\mathbf{2 5}$ chickens. The treatment ration and water were given ad libitum. Chicken were raised for 10 weeks. Experimental rations consisted of two treatments, namely $100 \%$ of commercial feed and $70 \%$ commercial feed $+30 \%$ corn. The commercial feed was purchased from PT Charoon Pokphan Ltd, Pekanbaru (Table 1), while the composition of nutrient content of treatment is shown in Table 2. The parameters measured were performance including feed intake, (BWG) and feed conversion ratio (FCR), concentration of TCHO in blood plasma.

Table 2 - The percentage of nutrient content of Corn and Commercial ration

\begin{tabular}{lcc} 
Nutrient & Corn* & Commercial ration \\
\hline Crude Protein (\%) & 8.6 & 23.50 \\
Crude Fiber (\%) & 2 & 1.88 \\
Crude Fat (\%) & 3.9 & 5.87 \\
Ca (\%) & 0.02 & 0.29 \\
P (\%) & 0.1 & 0.15 \\
ME (Kcal/kg) & 3,370 & 3,050 \\
* Scott et al. (1982). Ca: Calcium, P: Phosphor, ME: Metabolizable Energy; *Commercial feed: CP511 PT, Charoen Pokphand, Indonesia; \\
* Mineral Premix: Supplemented for kg of the diets: Vit. A, 12000 IU; D3, 2000 IU; E, 20 mg; K3, 3 mg; B2, 7 mg; B3, 12 mg; B5, 3 mg; B12, \\
0.03 mg; biotin, 0.1 mg; choline chloride, 300 mg; Mn, 130 mg; Fe, 70 mg; Zn, 60 mg; Cu,12 mg; l,1 mg; Se, 0.2 mg, and adequate antioxidant.
\end{tabular}

\section{Table 2 - Composition of nutrient content of treatment}

\begin{tabular}{lcc} 
Nutrient & $\mathbf{1 0 0 \%}$ of Commercial feed & $\mathbf{7 0 \%}$ commercial feed + 30\% corn \\
\hline Crude Protein (\%) & 23.50 & 22.01 \\
Crude Fiber (\%) & 1.88 & 4.21 \\
Crude Fat (\%) & 5.87 & 7.42 \\
ME (Kcal/kg) & 3,050 & 3,055 \\
\hline
\end{tabular}




\section{Growth performance}

Feed intake and BWG were recorded weekly throughout the experiment. Feed intake was corrected for body weight taking account of mortality if any. Feed intake was calculated as a difference between the amount of feed supplied to the birds and the amount of feed that remained at the end of each feeding period. BWG was calculated as a difference between the final and initial birds weight during each of the weighing periods. Feed intake and BWG were recorded at week 1 to week 10 and FCR was calculated as a ratio between feed intake and BWG for each period.

\section{Analysis of plasma total cholesterol}

The TCHO was determined with Microlab 300 (Vital Scientific, Netherland) as per the manufacturer's instructions. Samples were assayed together and in a random sequence for each sample.

\section{Statistical analysis}

Data obtained were analyzed by $\mathrm{T}$ test. Significant differences will be given in the symbol $p<0.05$. Data to be displayed was \pm SEM which is processed by SPSS commercial software (2007). Before data processing was performed, all raw data was performed by the Thompson test to eliminate outlier data using the test level $(p<0.05)$, then proceed with data analysis.

\section{RESULT AND DISCUSSION}

\section{Feed intake}

Weekly feed intake of the birds is shown in Table 3. T test results of feed intake, did not show significant effect $(P>0.05)$. Feed intake during the entire experimental period, ranging from 406.31 to $400.6 \mathrm{~g} /$ bird/week, respectively. This shows that substitution commercial feed with corn up to $30 \%$ did not affect feed intake. The result was consistent with previous work (Puspani et al., 2011) who revealed that substitution of commercial feed with corn up to $20 \%$ did not alter feed intake in broiler chickens. Similarly, Winarti and Wiranti (2013) who reported that substitution of broiler commercial feed with corn even up to $40 \%$ did not significantly change feed intake in native chickens. It seems that substitution of broiler commercial feed with corn did not alter feed intake thereby the composition of nutrients such as crude protein and energy metabolism in between two treatments given to KUB chickens still adequate to maintain their growth.

It is well know that level of protein and feed energy will affect the consumption of feed. Feeds that contain relatively similar protein and energy cause the same consumption of feed (Astuti, 2012). According to Parakkasi (1985) chickens consume rations mainly to meet their energy needs. Chickens cannot adjust to their rations precisely but consume more energy if their feed energy levels are low (Anggorodi, 1994). However, as shown at Table 2, the average feed intake of KUB chicken fed with substitution commercial feed with corn was 400.6 gram/bird/week higher than previous study (Munira et al., 2016) who found that the average of feed intake of KUB chickens was 307.80 grams / bird/week when fed a basal control diet prepared in 10-week. The reason for these discrepancies on feed intake due to KUB chickens is unknown. Such differences also might be attributed the size of the feed ingredient composition, feed formulation and feed pellet quality and management including environmental management, feed and water availability to the birds, disease control, and stocking density (Ferket and Gernat, 2006; Kuleile et al., 2020). These results also may imply that KUB chickens have a low nutrient requirement for maintenance and growth compared to broiler chickens. The trend of average weekly feed intake of KUB is shown in Figure 1. As shown in Figure 1 during the first 7 weeks, the average feed intake in chickens on both experimental rations increased gradually and showed similar trends. There was no increase in the feed intake of chickens during $8^{\text {th }}$ and $10^{\text {th }}$.

\begin{tabular}{|c|c|c|}
\hline Age (week) & $\begin{array}{l}\text { Control (broiler } \\
\text { commercial feed) }\end{array}$ & $30 \%$ substitution \\
\hline 1 & 99.52 & 90.96 \\
\hline 2 & 188.6 & 183.20 \\
\hline 3 & 265.6 & 244.80 \\
\hline 4 & 334.8 & 339.68 \\
\hline 5 & 413.4 & 409.60 \\
\hline 6 & 532.4 & 545.80 \\
\hline 7 & 559.2 & 546.60 \\
\hline 8 & 557 & 549.20 \\
\hline 9 & 556.2 & 546.20 \\
\hline 10 & 556.4 & 550.00 \\
\hline Average & 406.312 & 400.604 \\
\hline
\end{tabular}

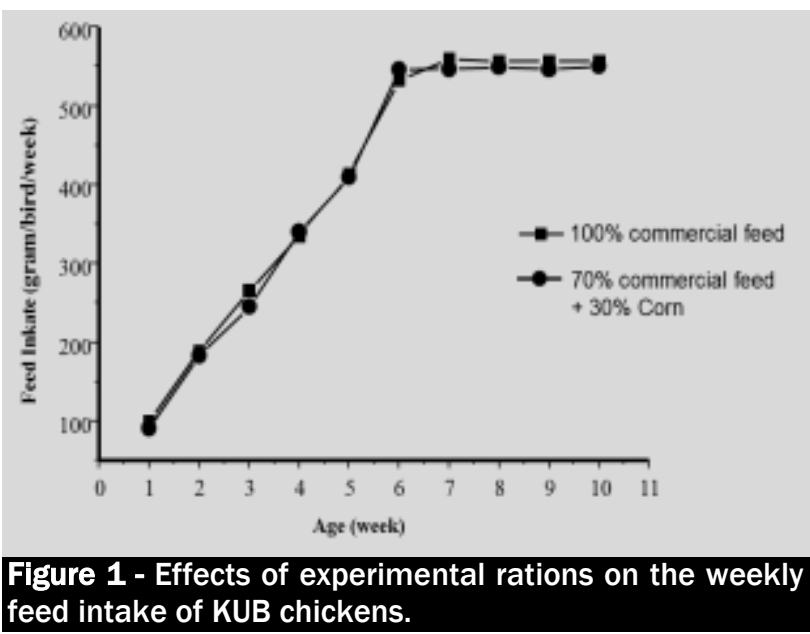




\section{Body weight gain}

Results of BWG of birds fed with experimental diets are presented in Table 4. The results of data analysis showed that the substitution of commercial feed with $30 \%$ corn did not significantly $(p>0.05)$ affect BW gain in KUB chickens. The average BW gain during 10 weeks old of was 487.0 and $420.5 \mathrm{~g} /$ head/week, control and substitution treatments, respectively. These results confirmed with previous work (Winarti and Wiranti, 2013) who found that reported that substitution of feed with corn up to $40 \%$ did not significantly alter BW gain in native chickens. This results might be attributed by feed intake were also similar of the two treatments. Visualization of the average weight gain of super native chickens during the study is shown in figure 2. As shown in Figure 2 that during the first 5 weeks, the average BW gain in chickens on both experimental rations increased gradually and showed similar trends. However, during $5^{\text {th }}$ and $10^{\text {th }}$ the average BW gain increased sharply. It seems that substitution broiler commercial feed had higher trend than control diet during $5^{\text {th }}$ and $10^{\text {th }}$. This shows that it is advisable to carry on keeping the KUB chickens until $10^{\text {th }}$ week as the chickens consumed more feed and gained gradually. These results indicate that the $5^{\text {th }}$ week was the period of the beginning of gradually growth which then continuously growth in sharply trend up to $10^{\text {th }}$ week.

\begin{tabular}{|c|c|c|}
\hline Age (week) & Control & Substitution \\
\hline 1 & 63.92 & 64.00 \\
\hline 2 & 99.28 & 122.72 \\
\hline 3 & 166.48 & 190.84 \\
\hline 4 & 233.88 & 243.12 \\
\hline 5 & 331.84 & 368.32 \\
\hline 6 & 396.16 & 491.16 \\
\hline 7 & 487 & 548.52 \\
\hline 8 & 546.32 & 639.40 \\
\hline 9 & 604.04 & 719.12 \\
\hline 10 & 689.4 & 818.24 \\
\hline Average & 487.00 & 420.54 \\
\hline
\end{tabular}

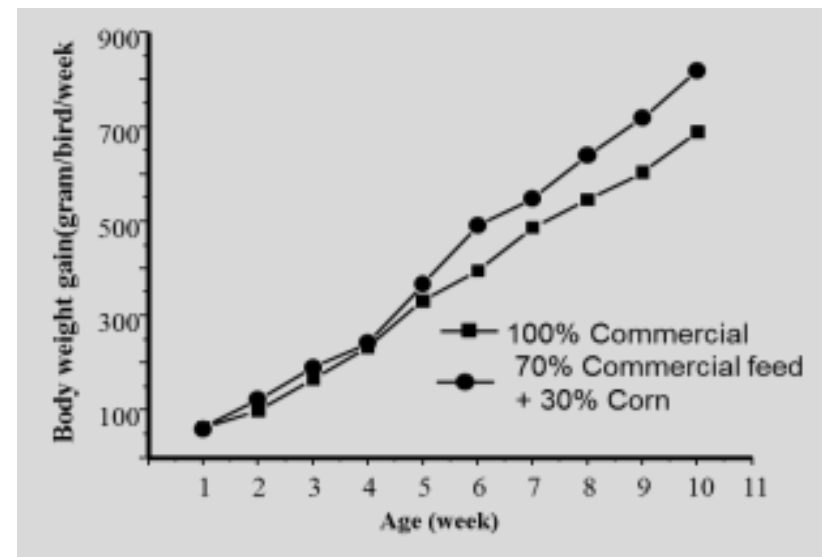

Figure 2. Average of BWG of KUB chickens in feeding substituted with corn

\section{Feed conversion ratio}

The average FCR for 10 weeks g /bird/week raised from lowest to highest respectively 4.78 and 5.0 as in Figure 3 . The results of the data analysis show that the replacement of commercial rations with corn did not significant effect $(P>0.05)$ on FCR. The results of this study were not much different from the results of the study of Munira et al. (2016) who demonstrated that the average FCR in super native chickens up to 10 weeks of age with substitution of fermentation rice bran was ranging from 4.1 to 4.9

\section{Economics of production}

Economic analysis as influenced by substitution commercial feed with $30 \%$ corn is shown in Table 5 . Total input cost per bird was calculated on the basis of total feed cost and cost of chicks and cost management. As KUB chicken fed on substitution commercial feed with $30 \%$ corn the cost of experimental ration decrease. Net profits were obtained for the group compared to fed by $100 \%$ of commercial feed.

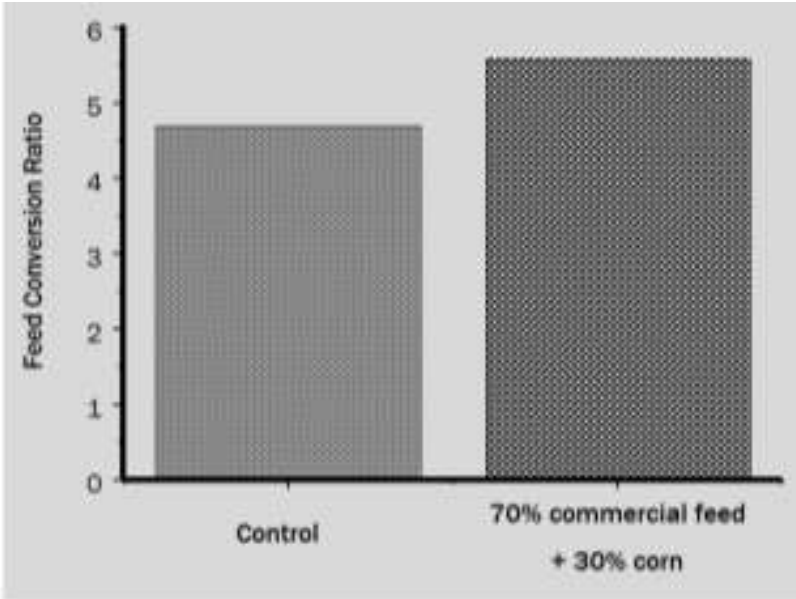

Figure 3 - Effects of experimental rations on the weekly feed conversion ratio of KUB chickens

\begin{tabular}{|c|c|c|}
\hline Parameters/rations & $\begin{array}{l}\text { Control (broiler } \\
\text { commercial } \\
\text { feed) }\end{array}$ & $\begin{array}{c}70 \% \\
\text { commercial fee } \\
+30 \% \text { corn }\end{array}$ \\
\hline Cost* of feed & 577,500 & 502,500 \\
\hline Cost of chicks & 350,000 & 350,000 \\
\hline Cost of management & 350,000 & 350,000 \\
\hline Total cost & $1,277.500$ & $1,202.500$ \\
\hline Sale revenue & 2,000000 & 2,000000 \\
\hline Average & 722,500 & 797,500 \\
\hline
\end{tabular}




\section{Total cholesterol}

The results of the study of commercial feed substitution with corn feed ingredients on TCHO of KUB chicken plasma is shown in Figure 4. Based on statistical analysis, there is no effect of experimental rations TCHO levels ( $p>0.05$ ). Study of plasma metabolites in bird enables metabolic change to be evaluated that are due to the effects of many factors, including pharmacological condition physiological state, age, husbandry condition, and genetic type (Meluzzi et al., 1991; Gayathri et al., 2004; Erwan et al., 2014, 2017, 2020). The average TCHO level in the control and substitution with 30\% corn was $154.52 \mathrm{mg} / \mathrm{dl}$ and $166.42 \mathrm{mg} / \mathrm{dl}$ included in the normal range according to finding of Mangisah (2003) who explained that normal chicken blood cholesterol levels ranged from $125-200 \mathrm{mg} / \mathrm{dl}$.

Partial substitution of commercial feed with corn feed ingredients did not affect TCHO. No differences TCHO levels presumably correlated to feed ingredients both treatments were similar. This result shows that substitution $30 \%$ commercial broiler feed with corn still could be tolerate on plasma metabolite especially TCHO in plasma. TCHO derived from feed plays an important role, because it is the main sterol in the body and the cell surface components and intracellular membranes. De novo cholesterol biosynthesis is much influenced by stress factors of super native chickens. Overal these results indicated that KUB chicken fed by substitution commercial feed with $30 \%$ corn did not adverse performance and plasma cholesterol .

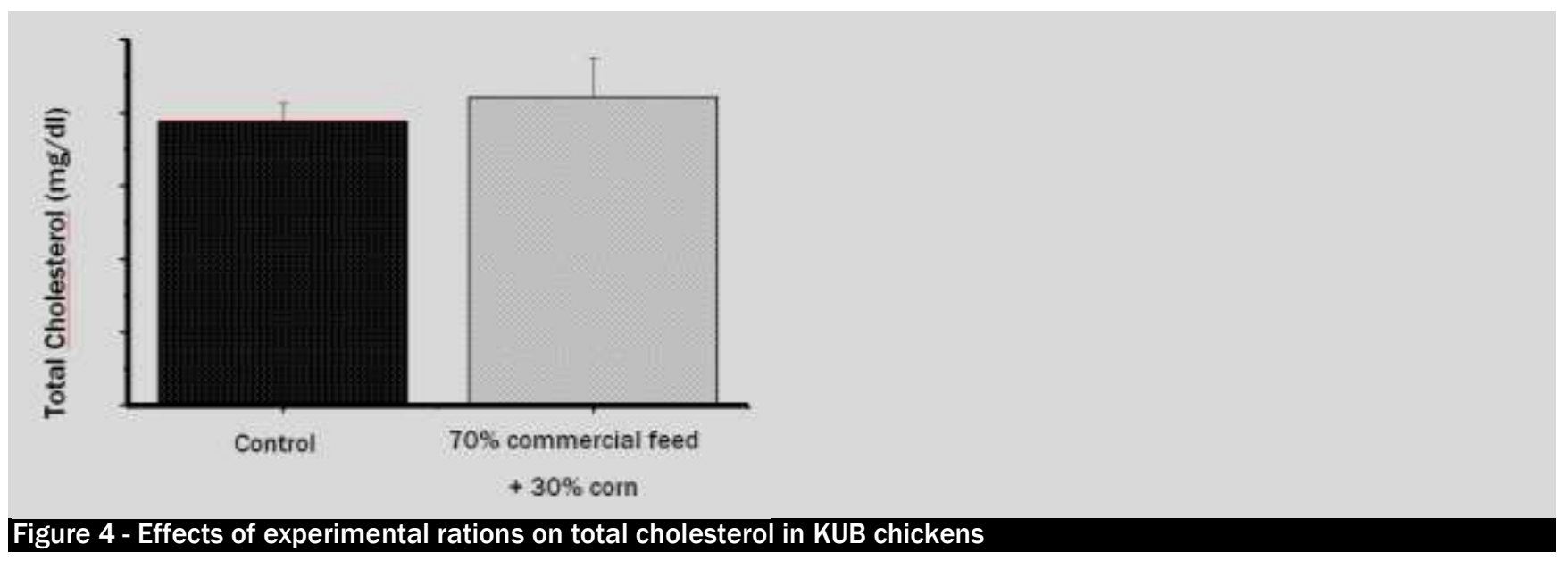

\section{CONCLUSION}

It is concluded that corn could be used up to $30 \%$ to substitute commercial feed in diets of KUB breed chickens (local breed) could reduce cost of production without change growth performance and plasma cholesterol level in local breeds of broiler chickens. A future study will explore on the effect of using $30 \%$ to substitute commercial feed on performance and plasma metabolites in other poultry species.

\section{DECLARATION}

\section{Corresponding author}

Edi Erwan, Ph.D. Department of Animal Science, Faculty of Agriculture and Animal Science, State Islamic University of Sultan Syarif Kasim Riau, 28293, Indonesia, email: erwan_edi@yahoo.com

\section{Availability of data}

The data can be availed to the journal upon request.

\section{Consent to publish}

Not applicable

\section{Conflict of interest}

The author declares they have no competing of interests.

\section{REFERENCES}

Astuti N (2012). Kinerja Ayam Kampung dengan Ransum Berbasis Konsenrat Broiler. Jurnal AgriSains, 4; $5.51-58$. Available at: http://ejurnal.mercubuana-yogya.ac.id/index.php/Agrisains/article/view/49

Anggorodi R (1994) IImu Makanan Ternak Umum. Penerbit PT Gramedia Jakarta.

Bakrie B, Andayani D, Yanis M and Zainuddin D (2003). Effect of Jamu addition into drinking water on the consumer preference and carcass quality of native chicken. Seminar Nasional Teknologi Peternakan dan Veteriner. Puslitbang Peternakan. Pp. $490-495$.

Central Bureau of Statistics (2017). Population of native Chickens by Province. Link https://riau.bps.go.id 
Erwan E, Chowdhury VS, Nagasawa M, Goda R, Otsuka T, Yasuo S and Furuse M (2014). Oral administration of D-aspartate, but not L-aspartate, depresses rectal temperature and alters plasma metabolites in chicks. Life Sciences, 109: 65-71. D0I: https://doi.org/10.1016/j.Ifs.2014.05.015

Erwan E, Zulfikar, Saleh E, Kuntoro B, Chowdhury VS and Furuse M (2017). Orally administered D-aspartate depresses rectal temperature and alters plasma triacylglycerol and glucose concentrations in broiler chick. The Journal of Poultry Science, 54:205-211. DOI: https://doi.org/10.2141/jpsa.0160010

Erwan E, Adelina T, Koto A and Maslami V (2020). The Potency of Oral Administration of L-Citrulline as Anti Heat Stress Agent in KUB Chickens. Journal of World Poultry Research, 10: 36-40. DOI: https://dx.doi.org/10.36380/jwpr.2020.5

Ferket PR and Gernat AG (2006). Factors That Affect Feed Intake of Meat Birds: A Review International Journal of Poultry Science,5: 905-911. DOI; https://doi.org/10.3923/ijps.2006.905.911

Gayathri KL, Shenoy KB and Hegde SN (2004). Blood profile of pigeons (Columba livia) during growth and breeding. Comparative Biochemistry and Physiology - Part A: Molecular \& Integrative Physiology , 138:187-92. DOI: https://doi.org/10.1016/j.cbpb.2004.03.013

Harianto, H., Kusnadi, N., \& Paramita, D. A. (2019). The Impact of Vertical Integration Intensity on Broiler Farms Technical Efficiency: The Case of Contract Farming in West Sumatera. Tropical Animal Science Journal, 42(2), 167-174. D0I: https://doi.org/10.5398/tasj.2019.42.2.167

Hidayah R, Ambarsari I and Subiharta S (2019). Study of physical, nutritional and sensory properties KUB chicken meat in Central Java. Jurnal Peternakan Indonesia, 21: 93-101. DOI: https://doi.org/10.25077/jpi.21.2.93-101.2019

Kuleile N, Ncheche Kh, Kamoho S, Macheli T, Jobo T, Phororo M (2020). The effects of broiler feed forms on metabolic and skeletal disorders. Online Journal of Animal and Feed Research, 10(3): 125-130. DOI: https://dx.doi.org/10.36380/scil.2020.0jafr17

Mangisah I (2003). Pemanfaatan Kunyit (Curcuma Domestica) dan Temulawak (Curcuma Xanthorrizha Roxb) Upaya Menurunkan Kadar Kolesterol Daging Ayam Broiler. Jateng: Balitbang.. DOI: https://doi.org/10.36762/jurnaljateng.v1i2.32

Meluzzi A, Primiceri G, Giordani R and Fabris G (1991). Determination of blood constituents reference values in broilers. Poult Science, 71: 337345. DOI: https://doi.org/10.3382/ps.0710337

Munira S. Nafiu LO and Tasse M (2016). Performans ayam kampung super pada pakan yang disubttusi dedak padi fermentasi dengan fermentor berbeda. JITRO, 3 :21-29 . Doi: https://doi.org/10.33772/jitro.v3i2.1683

Padhi MK (2016). Importance of indigenous breeds of chicken for rural economy and their improvements for higher production performance. Scientifica, 2016:1-9. DOI: http://dx.doi.org/10.1155/2016/2604685

Parakkasi A (1985). IImu Nutrisi dan Makanan Ternak Ruminansia. UI Press, Jakarta.

Puspani E, Nuriyasa IM, dan Candrawati Dsk. PMA (2011). Pengaruh Tingkat Penggantian Ransum Komersial Dengan Jagung Terhadap Komposisi Fisik Karkas Broiler yang Dipelihara Pada Ketinggian Tempat ( Altitude ) yang Berbeda. Majalah IImiah Peternakan , 14: 5-10. . Available at: https://ojs.unud.ac.id/index.php/mip/article/view/9219/6958

Pusat Data dan Sistem Informasi Pertanian Sekretariat Jenderal Kementerian Pertanian (2015). Outlook Komoditas Pertanian Subsektor Peternakan Daging Ayam. ISBN. 907-150, Page 17.

Sartika T (2016). Panen Ayam Kampung 70 hari. Penebar Swadaya, Jakarta.

Scott ML, Neisheim MC and Young RJ (1982). Nutrition of The Chickens and Pub. M.L. Scott and Assac Ithaca. New York.

Suarni dan Widowati S (2007). Struktur, Komposisi, dan Nutrisi Jagung. Jurnal Teknik Produksi dan Pengembangan Jagung. Available at:: http://balitsereal.litbang.pertanian.go.id/wp-content/uploads/2016/11/tiganol.pdf Page: 419

Teguia A and Beynen AC (2005). Alternative feedstuffs for broilers in Cameroon. Livestock Research for Rural Development 17 (3): 34 . Available at: http://www.Irrd.org/Irrd17/3/tegu17034.htm

Winarti E and Wiranti EW (2013). Pengaruh penggantian sebagian pakan komersial ayam broiler dengan bahan pakan lain terhadap pertumbuhan ayam kampung dan pendapatan peternak. Jurnal Pengkajian dan Pengembangan Teknologi Pertanian, 16: 223-229. Dol: http://dx.doi.org/10.21082/jpptp.v16n3.2013.p\%25p

Yakubu, A., Bamidele, O., Hassan, W.A. et al. Farmers' choice of genotypes and trait preferences in tropically adapted chickens in five agroecological zones in Nigeria. Tropical Animal Health and Production, 52, 95-107 (2020). D0I: https://doi.org/10.1007/s11250-019-01993$\underline{0}$ 